\title{
Introduction. The Moral and Affectual Dimension of Collective Action in South Asia
}

Amélie Blom et Nicolas Jaoul

\section{(2) OpenEdition}

\section{Journals}

Édition électronique

URL : http://journals.openedition.org/samaj/1912

DOI : $10.4000 /$ samaj. 1912

ISSN : $1960-6060$

Éditeur

Association pour la recherche sur l'Asie du Sud (ARAS)

Référence électronique

Amélie Blom et Nicolas Jaoul, «Introduction. The Moral and Affectual Dimension of Collective Action in South Asia », South Asia Multidisciplinary Academic Journal [En ligne], 2 | 2008, mis en ligne le 31 décembre 2008, consulté le 30 avril 2019. URL : http://journals.openedition.org/samaj/1912 ; DOI 10.4000/samaj.1912

Ce document a été généré automatiquement le 30 avril 2019

\section{$\Theta \Theta \Theta \Theta$}

This work is licensed under a Creative Commons Attribution-NonCommercial-NoDerivatives 4.0 International License. 


\title{
Introduction. The Moral and Affectual Dimension of Collective Action in South Asia
}

\author{
Amélie Blom et Nicolas Jaoul
}

1 'No politics' says the roaring tiger that illustrates this special issue of SAMAJ. This sticker was bought from a street vendor in Kanpur, a city located in the Indian state of Uttar Pradesh, during a celebration of the Ambedkar jayanti (birthday commemoration) in 2008. It is highly indicative of the way emotions can be valorized as pure and authentic expressions from the body, and pitted against regular politics, stigmatized as the impure realm of politicking, deals and compromises. This explicit denial of politics, however, seems too assertive to be taken for granted. It instead brings emotion back into the semantic field of politics, albeit politics at its first degree, as pure natural, and idealized reaction, a kind of 'darwinian' instinct of survival. The anger of the tiger can only result from its feeling of being in danger, which justifies its determination to attack; in other words, there is no compromise when the feeling of being under threat arises.

2 The passage from animal nature to human pride is revealing: natural instinct becomes a metaphor for human emotions, while the defence of one's cultural values seems to call for uncompromising and heroic behaviour. The tiger icon interestingly resembles the Mumbai-based Shiv Sena's emblem, an organization that has appropriated the Bollywood hero's anger at injustice as its theatrical marque de fabrique. ${ }^{1}$ But the fact that it was found in a Dalit meeting also points to the circulation, and wide and popular acceptance of these ideas that are presented as 'natural'. The popular politics of emotion and its use by different actors, whether inside or at the margins of the conventional political field, is what this special issue of SAMAJ seeks to explore through various examples taken from across the Subcontinent. 


\section{'Outraged communities' in South Asia's contemporary history}

3 'There is no collective action without perceiving, communicating, dramatizing and legitimizing an experience of indignation' (Cefai 2007: 163). The South Asian cases presented in this issue indeed testify to a particularly acute sense of outrage in collective action. Although not devoid of political claims, they are mainly articulated around expressions of moral discontent, claims for reparation or calls for revenge.

4 Communal conflicts caused by ritualized provocations and subsequent feelings of moral outrage have a long history in the Indian Subcontinent dating prior to British colonization (Baily 1985; Gaborieau 1985). The 1857 revolt itself was triggered by Indian soldiers refusing to open cartridges that contained beef and pig substances, thus breaking their religious taboos. As shown by the Cow Protection Movement initiated by the radical nationalist B.G. Tilak in the late $19^{\text {th }}$ century, such defence of community values or religious symbols became a method of popular mobilization that played an important part in the mass politicization that occurred subsequently (Freitag 1989; Pandey 1990).

Interestingly, such popular mobilizations on issues of outrage decreased only temporarily, and not totally after Independence, when angry crowds continued to display publicly their communal sensitivities, and took to the streets with remarkable regularity. To cite only the most historically significant cases, the Dravidians protested in the 1950s against the imposition of the Hindi language (Assayag 2001), while Pakistan witnessed a violent anti-Ahmadi campaign organized by Islamic groups irked by their heterodoxy. The 1980s marked a new height in such 'politics of outrage' by communal organizations. Sikhs mobilized after the desecration of the Golden Temple (1984); Muslims protested against Salman Rushdie's and Taslima Nasreen's novels (1988-89 and 1994 respectively), and, more recently, against the Danish caricatures of Prophet Muhammad (2006); Hindu nationalists rose from political marginality to regional state power in the wake of their campaign against Ayodhya's Babri Masjid in the early 1990s; since the late 1990s, Ambedkarite Dalits have also resorted to violence after the Ambedkar statues were desecrated, etc.

Such movements have deeply marked the Subcontinent's recent history. While these events attracted much scholarly and media attention, they are like 'big trees' hiding the 'forest' of numerous small scale and local events that are reported everyday in the local press. For instance, in India recently, a conflict erupted in Singur against forcible land acquisition: a peasant refusing to part with his land was quoted saying that 'land is like a mother. I'll never sell my mother' (Le Monde $6^{\text {th }}$ September 2008). This statement shows that even land-related conflicts that are not 'communal' and that one would expect to be fought on other grounds, can easily acquire the same affectionate overtones as communal ones, indicating the pervasiveness of the language of outrage in South Asian collective action.

Mobilizations of 'outraged communities' in South Asia occur too often, cut across too many diverse communities, regions, nations as well as historical epochs, to remain treated as isolated case studies. This special issue was prompted by such an observation. ${ }^{2}$ Indeed, it seems to indicate that mobilizations over outrage constitute a specific pattern of public assertion and collective action. They could even be considered a singular 
thematic pattern of what Charles Tilly calls a repertoire of collective action, i.e. inherited and constantly reactivated methods and rituals of public protest that run through time and make for the continuity of popular means of protests across historical epochs and regimes, enabling and constraining collective action concurrently (Tilly 1986).

The framing of discontent into the vocabulary of moral outrage, as well as the public emotions they entail, the popular rhetoric and use of moral values, the strong affective implications and the routinized, yet always innovative, pattern in which such moral and emotional claims are publicly manifested, constitute, in our view, specific dimensions of South Asia's political culture that call for a thorough investigation. But we would like to clarify any misunderstanding regarding our use of the notion of 'culture'. The culturalist trap that consists of taking culture as the ultimate explanation of human action can be avoided, if we follow a more dynamic approach to culture, where individual actions instead become accountable for the uses, the continuation of and the changes in culture. As James Jasper has noted:

Strategizing, in particular, is a matter of sometimes following culturally ingrained rules but at other times bending them, breaking them, playing off them to thwart expectations. As Swidler shows, strategies put culture into action /.../ Socially constructed meanings and practices can exert considerable constraint or provide equal room for creativity (Jasper 1997: 52).

The comparative perspective adopted in this volume will help us delineate more precisely the dynamic features of the politics of outrage. We also hope that it will provide some insight on South Asia's vibrant and enduring culture of public dissent.

\section{The complex politics of South Asian 'outraged communities'}

10 The recrudescence of communal violence in South Asia since the 1980s has led to a scholarly focus on violence, from questions regarding crowd behaviour to more systemic overviews of the politics of communal violence. Yet, outrage has not been addressed as such. Paul Brass (1997) convincingly demonstrates how communal violence can become institutionalized in certain local set ups and highlights the subtle division of labour between a whole range of local actors involved in such conflicts. His emphasis on manipulation, however, fails to give an account of the reasons why ordinary people can play a game in which they often end up as the victims. He thus considers as mere pretext what he calls 'precipitating incidents' (Brass 1997: 6), that are, if not fabricated, then at least exploited in order to make purposely built communal tensions degenerate into violence.

11 In the same manner, Stanley Tambiah (1996), in his often praised, comprehensive and comparative study of South Asian communal riots, seeks to take into account their psychological intensity, but fails to deal in a satisfying manner with the popular narratives and moral justifications that accompany and even inform such violence. In his list of elements conducive to communal violence, the fifth and, significantly perhaps, also the last is: 'an array of 'triggering actions' that are publicly recognized as challenges, slights, insults, and desecrations inviting reprisal' (Tambiah 1996: 233). ${ }^{3}$ It is interesting to note that he consigns such 'triggering events' to the realm of timeless and borderless 'rumours' that 'cluster around themes and issues repeated again in history in diverse places and times' (Tambiah 1996: 236). Hence, the question of outrage is again relegated 
to the background, and opposed to 'a number of other interests and differences, whose contention and resolution are also at the heart of the matter' (Tambiah 1996: 234).

There is no point in denying the causal importance of such social, political and economic stakes that can make communal violence a viable option for certain actors whose immediate political calculations it matches. By highlighting them, authors, such as Brass and Tambiah, certainly made a major contribution to the proper understanding of communal conflict in South Asia, and also gave a decisive blow to the essentialist conceptions that took such conflicts for granted. Yet, the main shortcoming of the instrumentalist school is to ignore the popular agency and meanings that are actively involved in the production of communal violence. The 'precipitating incidents', that form the rough material of outrage, should in fact be treated as highly meaningful and crucial. In order to precisely find out the popular stakes of protests (from conventional and accepted repertoires of collective action to more or less organized forms of violence), an understanding of their moral incentives or 'justifications' is required.

As the French critiques of the theories of ethnicity Jocelyne Streiff Feinart and Philippe Poutignat (1995) have argued, the instrumentalist paradigm inadvertently falls back on the very same essentialist notions that it seeks to combat. A case in point is Tambiah's proposition that there is a lack of shared values in such conflicts, a somewhat culturalist postulate, which takes for granted or overestimates the 'cultural gap' between religious communities. The syncretism argument, highlighting all that communities culturally share across communal boundaries, has rightly been criticized as 'naïve', and it has also been noted that it corresponds in India to the official secular ideology of the Congress Party (Gaborieau 1985).

Beyond this argument, several works more interestingly point to some degree of ideological unity between diverse communal discourses, despite the fact that their aim is to emphasize cultural difference. For example, Christophe Jaffrelot (1996) has analyzed the imitation of the Khilafat movement by the Hindu Sangathan movement in the early 20 th century in spite of its clear-cut opposition to Muslims; a conscious mimetic process that he has labelled 'strategic syncretism'. In an article on the Sikh pogroms of 1984, Veena Das (1998) also shows how pre-existing nationalist narratives and representations of the nation resurface in communal narratives as well as in popular stereotypes on Sikh violence. She notes that 'no matter at what point one chooses to begin a story, there is always a prior story waiting to be activated, one that has been lying inert or circulating' (Das 1998: 110).

Reflecting upon $19^{\text {th }}$ century popular mobilizations in 'public arenas', Sandria Freitag emphasizes that 'the resulting cultural expressions offered alternative ideologies to those forged in the state's political realm', which created 'shared values' and 'a shared language in which to argue' (Freitag 1996: 213, 217). She also brings to our notice the 'passionate devotionalism' adopted by individuals in the defence of collective claims. She proposes a list of recurring features of public arena mobilizations that point to their unity: community, state, dramatic moments, special vocabulary, claims in public, swaying public opinion, mobilization in the streets featuring violence, and creation of an 'Other' (Freitag 1996: 219, 220-2). Thomas Hansen (2005) also makes a decisive step towards a unified comprehension of South Asian communalist movements' discourses when he points to their common claim to sovereignty that competes with the state's public authority over what they claim to be 'their' social constituencies. He thus argues that despite their conflicting claims, such movements are equally based on the notion of "communities' as 
the natural repositories of morality and ethical life in India, separated from, and conceptually opposed to, the "state" (Hansen 2005: 124).

The instrumentalist paradigm provides a top-down explanation focusing exclusively on the fulfilment of elite interests and in which elites are often caricatured as utilitarian and manipulative (while the popular base is seen as manipulated and alienated). The so-called 'moral economy' approach provides a better understanding of what motivates people to actually become involved in riots and other forms of street agitations. This idea, developed by E.P. Thompson (1991), and the academic reflection that came out of it, proves to be more heuristic in our exploratory approach towards the articulation of collective action and moral outrage. Although it has a loose and unsatisfying definition, and although the term 'moral economy' itself is employed in a metonymic manner that is clearly confusing, the approach remains extremely rich in the possibilities it creates for the analysis of the ambiguous linkage between popular insurgencies and the consensual realm of moral values.

17 The moral economy approach probably appeared in the 1830s 'in a polemic against political economists', whose defence of Adam Smith's theory of economic liberalism was opposed to the old economy of subsistence based on local patronage of the rural elites (Thompson 1991:337). While the $18^{\text {th }}$ century food riots in England had generally been considered to be the mere mechanic reactions of the belly prompted by bad harvests and dearth (a conception that Thompson dismisses as a 'spasmodic view' of history), the historian reintroduced the insurgents' moral incentives and claims. He emphasizes the subaltern uses of such patronage for food security purposes, and focuses on the popular uses of consensual moral values for their own perceived economic interests (even if it is limited to food security and has nothing revolutionary). In a departure from the political economists' narrow and monopolistic definition of economic rationality, Thompson thus renews the historiography of popular revolts by stressing the claims, modalities of action and moral values of the insurgents, which help him identify a specific popular agency (a sort of 'pre-class' consciousness of the toiling masses).

Although Thompson's definition of the moral economy remains an economic one,${ }^{4}$ he engages in a wider theoretical discussion regarding the popular uses and understandings of 'shared values', especially during popular insurgencies. Indeed, it is chiefly in the name of preserving established moral values that insurgents try to defend the old patronage model. In his review of the critiques, and academic uses, of the notion of 'moral economy', Thompson acknowledged that he welcomed its expanded use:

The deep emotions stirred by dearth, the claims which the crowd made upon the authorities in such crises, and the outrage provoked by profiteering in lifethreatening emergencies, imparted a particular 'moral' charge to the protest. All of this, taken together, is what I understand by moral economy (Thompson 1991: 338).

19 However, by neglecting to clarify the notion's ambiguity, the 'moral economy' school has nurtured a confusion between its strictly economic aspect, and the wider theoretical issue of the popular uses and meanings associated with moral values in relation to their more established (elite) definitions. The 'moral economy' indeed ends up standing for the more conceptual question it raises, giving the term 'moral economy' a metonymic connotation. The same lack of conceptual clarity is palpable in James Scott's attempt to strengthen the 'moral economy' argument. For example, in his innovative ethnography of Malaysian peasants, he states that 'the subsistence ethic is not only a given of peasant economics, but [...] has a normative or moral dimension as well' (Scott 1976: 11). 
catch-all use of the 'moral economy' notion may seem slightly confusing (by mixing indistinctly the moral economy proper with what could also be called the subaltern 'economy' or 'grammar' of moral values). It is actually Thompson's concern with popular agency as cultural, pre-Marxist (or embryonic) expressions of class, rather than with the more specific and historically located popular defence of the old economy against the increasingly capitalist economy, that has inspired reflections on the issue of subaltern agency.

21 Such is the case with prestigious works like the Subaltern Studies in India and James Scott's second book (Scott 1985) on everyday forms of peasant resistance in South East Asia, for which he has coined the highly successful notion of 'weapons of the weak'. The emphasis on moral values is even clearer in his later book (Scott 1990) where he analyzes the passage from unorganized and constrained means of resistance of the seemingly abiding, but cunningly, resisting peasants to more assertive and organized protests (i.e. the politicization process that passes from 'hidden transcripts' to public assertion of a 'dissident subculture'). Scott evokes the strategic importance for the dominated strata of society to remain identified with the dominant values (instead of criticizing them for the part they play in justifying the status quo), even during revolts:

The fact is that the public representations of claims by subordinate groups, even in situations of conflict, nearly always have a strategic or dialogic dimension that influences the form they take. Short of the total declaration of war that one does occasionally find in the midst of a revolutionary crisis, most protests and challenges-even quite violent ones-are made in the realistic expectation that the central features of the form of domination will remain intact. So long as that expectation prevails, it is impossible to know from the public transcript alone how much of the appeal to hegemonic values is prudence and how much is ethical submission (Scott 1990: 92).

The ethnographic study of moral aspects of protests can thus provide important clues on how specific claims and discontent of the lower class may fuel rightist or communal movements, whose ideology originates from the elites rather than being moulded by specific interests or reflecting assertive world views of the unprivileged. This has for example been noted regarding the popular response to the Hindu Nationalists' Ayodhya mobilization, whose ideological content was conservative and politically designed to counter the political mobilization of the lower castes (Basu 1993). Yet, there is still a need to renew our understanding of the ever changing, infinitely complex and contradictory popular relation to ideological frameworks that originate 'from above' but can always become appropriated 'from below'-and be partly subverted or deviated from their original political aims.

Indeed, several historians of popular dissent in colonial India point to this Janus-faced dimension of communal conflicts, in which practical contestation against exclusion from the public sphere by the lower class becomes entangled into a generally conservative communal rhetoric, thus limiting the possibility of fulfilling such assertion. For example, Nandini Gooptu's (2001) work on the urban poor's collective action in early $20^{\text {th }}$ century north India, shows that the participation of the poor in communal processions, led and financed by conservative sections of the urban middle class, had a distinct political meaning from that of the organizers. Based on detailed historical ethnography, she shows that the lower caste poor joined with a separate, underlying (even if unformulated) agenda: physical contestation of their political exclusion from local governance, of their powerlessness, of their precariousness, and their vulnerability in the face of violent

South Asia Multidisciplinary Academic Journal, 2 | 2008 
police and municipal drives of slum evictions. Public assertions of religious communities in which the poor were the main participants thus relied upon contradictory expressions of class, 'both as theatres of self-representation or affirmation of power of the dominant classes, and as vehicles of contestation from below' (Gooptu 2001: 21). In other words, 'all these various forms of politics of the poor were animated by their urge to defy exclusion and to entrench their presence in the public sphere' (Gooptu 2001: 422-3); a physical statement that encapsulates a kind of self-restrained and politically twisted lower class agenda.

As the case studies included in this issue show, staged outrages provoked by such distinct events like the public lynching of a Dalit family (see Jaoul), the publication of offensive cartoons (see Blom), books or textbooks (see Riaz, Ali), a community leader's 'sacrilegious' use of religious symbols (see Baixas \& Simon), an alleged attack on Hindutva activists in a train (see Hansen), the destruction of Buddha's statues (see Centlivres), or the alleged destruction of a mythical bridge (see Jaffrelot), follow distinct, and perhaps even conflicting, political agendas. However, by looking closer and in detail at the ideological content and methods used by those who staged these reactions of outrage, we insist on paying attention to the uses and meanings of values that are both shared and disputed. In the following section, we propose to explore the sociological properties of 'outrage', as well as the intricate ways in which outrage articulates moral values and powerful emotions.

\section{Outrage, anger, and power relations}

Outrages, like insults, are often perceived as the very negation of politics (Bouchet 2005: 8). Indeed, they are so emotionally charged, triggering anger or even hatred, and can be so devastating, breaking all possible dialogue, that they seem to negate the very idea of mutual recognition, and pervert the very foundations of political relations. Consequently, this social reality remains at the margins of studies in political science, sociology and anthropology (unlike other moral categories such as respect or dignity).

Unquestionably, the notion of outrage is ambiguous, as proven by the contradicting definitions provided by French and English language dictionaries. In French, it is associated with 'offence', and understood as 'an act that goes gravely against a rule or a principle' (Le Petit Robert). The offended alone evaluates the level of 'gravity', in accordance with a set of norms he/she expects to be followed in human interactions. Sociological approaches borrow from this cognitive approach: outrage is defined as a 'complex cognitive understanding and moral awareness, reflecting our comprehension of the world around us and sometimes of our place in it' (Goodwin et al. 2004: 418). Yet, an outrage is no mere cognitive process; it is deeply felt and provokes anger. The English language precisely stresses this emotional dimension: outrage is 'an intense feeling of anger and shock' (Collins English Dictionary). It is primarily defined by the emotion and almost physical reaction it provokes.

Outrage is, in fact, at the juncture between the moral and the emotional realm, and this duality (from the point of view of an obviously too neat a set of categories, if we consider that emotions, cognition and morality are in fact deeply intertwined and inseparable concepts) is precisely what interests us. The common sense helps us to understand this dimension. When we say 'it is outrageous', we experience something deeper than a principle-based evaluation: we are emotionally shaken and angry. Yet, we feel something 
more complex than reflex anger: we feel a righteous anger, grounded in our conviction to occupy the moral high ground. The South Asian case studies included in the present issue of SAMAJ clearly prove that instigating, staging and managing this 'righteous anger' is a crucial dimension in mobilizing 'outraged communities'. This is something that some social movements theorists have not failed to notice. William Gamson (1992), in particular, highlights the importance of outrage and anger in channelling potential participants towards collective action through an effective 'injustice frame'. It would be very difficult to motivate people to react to a perceived injustice without a 'hot button' or without 'the righteous anger that puts fire in the belly and iron in the soul' (Gamson 1992: 32).

Based on small group experiments, Gamson even shows that when people witness a transgression by an authority figure, they tend to have strong emotions of suspicion and anger while the blame is still to be allocated through a cognitive process. Movement leaders make a great effort to shift emotions from dread to outrage. In other words, they try to connect the abstract feeling of unfairness to moral indignation, in order to sustain the emotions that will otherwise dissipate. They have to 'weave together a moral, cognitive, and emotional package of attitudes' (Goodwin et al. 2001: 16) so as to convince people that the indignities of their everyday life can be attributed to some agents and that their condition can be changed by taking action collectively. In this perspective, outrage is an anger that is felt due to injustice, but one that has been efficiently framed by social movement entrepreneurs: there is someone to blame, responsibility can be attributed and solutions proposed. As the case studies in the present volume demonstrate, allocating blame is indeed a crucial element in setting 'outraged communities' into motion.

Feelings of injustice, as emphasized by the 'moral economy' approach, are linked to our own moral visions. The moral dimension of protest had no place in a crowd's emotional dynamics in studies done by pre-1960s scholars while the rationalist paradigms that followed erred in the opposite direction (all protests were now seen as the narrow, rational pursuit of interests). James Jasper (1997), one of the few social movement theorists to reintroduce outrage and the moral variable in our understanding of social protests, suggests that individuals are morally shocked by threats to their understanding, or to what they love and value, not merely scared or strategically calculating the right reaction:

Rather than simply or directly changing what they dislike-which may not be possible-, [social movements] also express their contempt and outrage over existing practices. It is their ability to provide a moral voice that makes protest activities so satisfying. They give us an opportunity to plumb our moral sensibilities and convictions, and to articulate and elaborate them. And it is important to articulate them publicly and collectively, two features which, sociologist Emile Durkheim insisted, deepen the significance and emotional impact of beliefs and feelings. Few other institutions in modern societies provide this kind of forum (Jasper 1997: 5, emphasis added).

Hence, social protests are born out of a 'moral shock'-that Jasper compares to an electric shock, which puts people in an 'attack mode' (Jasper 1997: 106). It can be triggered by a highly publicized event or a more localized insult; it can be sudden or gradual, dramatic or operating like the 'last straw' that finally spurs action.

31 Although 'moral shock, agency and activism have a complex relation' (Goodwin et al. 2001: 17), ${ }^{5}$ bringing the protestors' moral visions back in helps to 'reanimate the sometime 
robotic image of humans' (Lutz \& White 1986: 431), long advocated by the theories of collective action. It is particularly useful for our inquiry on types of protests in South Asia, wherein voicing moral discontent, asking for symbolic reparation or sometimes calling for revenge, is at the heart of the mobilization. The collective actions studied in this volume would hardly have happened if the particular event against which protestors mobilized-the publication of cartoons or the revision of textbooks' curriculum in Pakistan, the use of sacred symbols by a dissident leader or the collective lynching of a family in India, for instance (see Blom, Ali, Baixas \& Simon, Jaoul in this volume)-had not initially shaken the protestors' inner sense of morality and if they had not felt that they occupied the moral high ground when protesting. Yet, one important question remains unanswered: how precisely does a 'moral shock' operate?

Academic works on blasphemy - a prototypical form of outrage partaking of a similar 'ethnology of the forbidden' (Cheyronnaud \& Lenclud 1992: 261) - provide some useful answers. Like 'blasphemy', an outrage emerges and develops following a precise 'mechanism' or 'apparatus' (dispositif in French) as stressed by Jeanne Favret-Saada (1992: 257). ${ }^{6}$ This mechanism includes someone who denounces (1), a referent denounced as 'outraging' (2), and a given authority called upon to intervene (3). There is, indeed, no outrage without being perceived and labelled as such (Rouayrenc 1996: 112). Defining outrage as being, first and foremost, a performative act of language leads us to pay close attention to the particular 'regimes of justification' (Boltanski \& Thévenot 1991) used by any 'outraged community' and to its modes of generalizing the grievance in such a way that it can engage a group, hence calling for public recognition (otherwise it would be nothing more than a personal suffering).

It also invites us to look at how the denunciation is framed in order to make sense of what constitutes the fourth pillar of the outrage mechanism, i.e. an 'institutional setting' or 'repertoire of virtual interpretations and public sanctions that pre-exist and within which the actors are embedded without always having a clear knowledge about it' (Favret-Saada 1992: 257). Labelling a perceived insult to a religious symbol as 'blasphemy' in India, Pakistan or Bangladesh (see Baixas \& Simon, Blom, Riaz in this volume), all countries where Blasphemy Laws exist, but framing it instead as an attack to the 'cultural heritage' in France (see Centlivres in this volume), for instance, has to be understood in its specific context.

This discursive war does not render the 'condensing' object of outrage irrelevant to the study. That it can either be a word, an act or an image, is not inconsequential and shapes the forms of the 'outrage mechanism'. This volume actually includes an extremely diverse range of outrageous items or acts that recently provoked collective reactions in South Asia: drawings, printed words, dredging a canal, using religious symbols and committing mass murders. Not all is meta-narration of course. Thomas Bouchet recalls that one of the decisive characteristics of an insult, even when humorous, is that 'it is an act of violence [...] it denies its very name to its victim by imposing another one upon him/her. This process is enjoyable yet it can break an individual, even destroy him' (Bouchet 2005: 273). An outrage can generate humiliation such that it is often difficult, to repeat what has been said or done. As a result, the reaction it generates inescapably involves reclaiming agency and dignity, and displaying counter-emotions and norms in public demonstration of esteem and respect towards precisely what has been insulted.

An outrage often looks like a matryoshka: what is publicly denounced somehow envelops underlying and unvoiced offences. The 'Taslima Nasreen affair' is a case in point: the 
agitation was launched under the slogan of 'Islam in danger', but what seemed to have been really intolerable was the behaviour, free thought and social life of an upper-class, educated and professional young woman. ${ }^{7}$ The gender dimension, barely mentioned by Nasreen's detractors, sheds a different light on the controversy: it explains the extreme violence of the attacks against her (she not only had to be banned from her country of residence, or even killed, but also savagely humiliated), as well as the longevity and transnational dimension of the reactions. More than her writings, it was her very body and/or physical (public) appearances that her opponents were tracking. Nosheen Ali's contribution to this volume similarly emphasizes the smoke-screen characteristics of public reactions to outrage: albeit focusing on a seemingly sectarian issue, the Shia mobilization against offensive textbooks in Pakistan's Northern Areas, in the mid-2000s, was also at a deeper level the contestation of a long-standing regional subordination and denial of citizenship.

The prism of possible responses to an outrage is vast: belligerent silence, negation, irony, insulting back, threats, judicial complaints, collective actions, and so on (Bouchet 2005: 11). To understand why certain outrages provoke collective mobilizations, while others do not, the relational and situational dimension of an outrage has to be taken into account (Larguèche 2004: 35). An insult does not just unfortunately link the one who insults to the one who 'takes the blow', it also upsets, and eventually reshapes, their relation: by exacerbating old stigmatizations and resentments, or by creating new ones. As a matter of fact, there is no outrage "which is not in situation, particularly when we are interested in its political connotations or when we consider it a modality of political expression' (Verdo 2005: 15). It is frequently the context itself that gives to any given word or action its insulting character. The notion of 'outraged communities' coined here in order to emphasize, and explore, the emotional, albeit often ephemeral, bonds that an outrage provokes among those who experience it, does not render these collectivities into a-historical entities. On the contrary, all the articles in this volume emphasize that they are shaped in situ and at specific, often critical, historical junctures. More precisely, an outrage often takes its full meaning in the structure of pre-existing and historically situated relations of power and the corollary assertion of moral superiority that unavoidably accompanies them.

The feeling of anger that an outrage brings out has to be understood in this very context. For analytical reasons, we have considered so far the moral component of an outrage in isolation from its emotional dimension. But as stressed earlier, both are inter-functional: an outrage does not only cause a moral shock, it makes one (righteously) angry. Anger is a crucial component in collective mobilizations because it is a 'sanctioning emotion' (Flam 2005: 20). This is a point that anthropologist Robert C. Solomon has stressed forcefully:

Anger is not just a physiological reaction cum sensation plus an interpretation [...] it is essentially an interpretation, a view of its cause (more accurately, its 'object') and (logically) consequent forms of behaviour [...] it is 'a kind of interpretation [...] of the world. It is [...] a way of being-in-the-world, a relationship between oneself and one's situation. [...] Anger, in other words, is essentially a judgmental emotion, a perception of an offence (as Aristotle argued in Rhetoric) (Solomon 1984: 249-250). ${ }^{8}$ 
Klingemann 1996: 7) or in a Schmittian fashion as a 'foes versus friends' process, frequently operates by 'mobilizing anger' against one's opponents (Ost 2004: 239). Conversely, public responses to illegitimate orders and perceived injustices are rarely devoid of anger-although cynicism and/or resignation are also rational reactions. For Peter Lyman (1981: 61), anger is therefore, 'the essential political emotion'. It confronts any political order to a difficult dilemma: it is a resource because listening to anger may lead to a constructive public dialogue about the fairness of any political order (while repressing it can provoke more damaging resentment, rage and violence) but, because popular anger always threatens the dominant groups' status quo, it also has to be domesticated through force, moral righteousness, silence and technique. In any political order therefore, 'strong cultural and political norms that seek to suppress the expression of anger' co-exist with the equally important necessity of avoiding the danger of repressing it, i.e. 'that essential dialogues about injustice may be suppressed as well' (Holmes 2004: 127).

The reactions of 'outraged communities' in the public arena, and the state's response to them, strongly highlight this dilemma. Exhortations to (appropriately) express anger and encouragements-particularly towards subordinate, oppressed or excluded groups-to repress anger are intrinsic features of public politics. But once anger has (inappropriately) erupted in the public sphere, depoliticizing it takes a great deal of the challenged actors' time: angry demonstrators are said to be manipulated or irrational, as evidenced by the case of the young Lahori rioters who protested against the Danish cartoons. As shown by Amélie Blom's contribution in this volume, these rioters actually found a socially and politically legitimate opportunity to assert a long-felt and multifaceted anger through their protests. This actually points to a critical characteristic of 'outraged communities' when they confront more powerful groups or institutions: they have to reclaim the right to be publicly angry. Indeed, 'since [anger] normally constitutes the prerogative of the powerful', writes Helen Flam (2005: 20), 'social movements have to re-appropriate the right to feel and display this particular emotion by their members'. In his contribution to this volume, Nicolas Jaoul precisely describes the process of the Dalits' reappropriation of anger, and how the social mapping of legitimate expression of anger can be contested through the emotional work of social movements.

Without following Jack Barbalet (2001) when he argues that emotions in social life have principally to do with class resentment, we do consider outrage and anger to be intimately linked to a power relationship. Most of the case studies included in this volume demonstrate and explore this hypothesis, at the local and/or international levels, though not always addressing it directly. When mobilizing over an 'outrageous' event, socially or politically excluded groups-the Dalits in India, the Northern Area Shia minority and the urban middle-class youth in Pakistan for instance (see Jaoul, Ali, Blom) -, as well as marginalized political parties once they are not in power anymore (such as the BJP that Jaffrelot analyzes) and a diplomatically ostracized regime (such as the Taliban studied by Centlivres), fundamentally enact and/or contest power relations.

This might explain why the public reaction provoked by an outrage usually operates in a mirror-pattern: the outraging actors themselves reacting to an outrage felt previously; an interesting finding that most contributors to this special issue also highlight. This is true in the cases of T. Nasreen when she wrote Lajja in 1993, of the Taliban when they destroyed the Buddhas of Bamiyan in 2001 or of the Danish newspaper Jyllands-Posten when it published the cartoons representing the Prophet Muhammad in 2006 (see Riaz, 
Centlivres, Blom respectively). Sometimes, the prior outrage is not a particular event but the very fact that a subjugated group dares to challenge the structure of domination (the successful daughter of a Dalit family whose members were lynched in the Maharashtra village that Jaoul studies), or simply dares to exist politically (the Muslims that can be killed with impunity in the crowds, as Hansen analyzes in this volume).

Therefore, if we agree that an outrage is always perceived as an attack against one's moral values or dignity, while being grounded in pre-existing relations of power, then its public display also informs us about deeper structural changes affecting these very relations. As stressed by Claudine Haroche and Jean-Claude Vatin:

Consideration, recognition, deference, respect, dignity: these terms [...] qualify transitory, unstable, moving, intangibles yet crucial states. They [...] reflect the movements of links and relations formed in social systems, whose more or less structured nature varies according to places, societies and times (Haroche \& Vatin 1998: 9).

The historical recrudescence of communal mobilizations around issues of communal outrage in South Asia cannot be dealt with here, despite the importance of understanding this temporality, or precisely because of it, since it would require a much deeper study than the theoretical outlines that we intend to provide in this introduction. Yet, one cannot fail to notice that communal outrage became historically significant both in the early $20^{\text {th }}$ century and in the $1980 \mathrm{~s}-1990$ s, two periods that have witnessed strong movements of mass politicization. We nevertheless hope that the case studies that have been assembled here will provide material for such an endeavour.

\section{The politicization of emotions: A social movement perspective}

The long silence suffered by emotions ${ }^{9}$ in social movements' theories is certainly not based on their decreasing empirical importance in social protests. As stressed by Laurent Thévenot (1995: 147), because emotions are learnt in 'situations of exchanging expressions', one might 'quite naturally expect that emotions and their expressions play a role in every collective situation where what is at stake is to coordinate intentions, in particular in [...] collective mobilizations'. Owen Lynch makes a similar observation regarding the self-contradictory disinterest for emotions in anthropological works:

If the passions are precisely those structures which connect and bind us to other people (Solomon 1976: 19), then why until recently have anthropologists who claim to study the structures that connect and bind us into social and cultural systems, either considered them irrelevant or failed to question their assumed nature and operation? (Lynch 1990: 4).

Taking the emotional texture of collective mobilizations seriously provides an extremely rich entry point to study the politics of outrage in South Asia. However there is a long way to go towards understanding their translation into effective collective action; a gap forcefully encapsulated in a placard 'Anger into Action' held by a young woman during one of the street demonstrations organized in Mumbai after the 26-28 November 2008 attacks and captured by TV channels worldwide. The difficulty lies here in that 'the current state of knowledge concerning the relationship between emotions and contention is not sufficiently developed to allow for the construction of any systematic theoretical framework' (Aminzade \& McAdam 2001: 15). 

they were linked only to intrinsically 'emotional crowds', personality conflicts and psychological problems. This interpretative sliding from bodies (behaviours observed at a distance) to states of mind was undoubtedly problematic (Mariot 2001), and made emotions recede in the shadow afterwards. They had no place in the rationalist, structural, and organizational models that followed. These models, still dominant, consequently tell us a lot about how people act when they do not feel and fail to notice 'the emotional energy required for, and generated by disruption, rule violations, and collective political violence' (Aminzade \& McAdam 2001: 21). Although the 'collective action frame' perspective ${ }^{10}$ fruitfully reintroduced culture and perceptions to the discourse, it somehow reduced participants to 'computers mechanically processing symbols' (Goodwin et al. 2001: 1) or to 'Spock-like beings, devoid of passion and other emotions' (Bedford 1997: 419).

The cultural turn in social sciences, in the last decade or so, has led to the revival of emotions in the study of societies, and by extension of social movements and politics. Now emotions are back, but almost exclusively in studying 'egalitarian collectives', such as feminist, gay and lesbian, anti-nuclear, animal rights and victims' movements, etc.; these are furthermore movements exclusively based in America and Europe. The present issue of SAMAJ precisely aims at demonstrating that the broad analytical framework used in these recent works is as valuable for studying South Asian movements. The ambition is not to offer a new, 'better' and invariant model but simply to recall that 'the affectual and emotional dimensions of social movements are as important as the cognitive ones' (Goodwin \& Jasper 1999: 49). Truly, 'environmental circumstances, including strong organizations and favourable opportunities, will not produce a movement in the absence of heightened emotions', while 'widely acknowledged facilitators of mobilization operate in large part through the emotional dynamics they set in motion' (Aminzade \& McAdam 2001: 14).

Some false dualisms certainly need to be clarified. The first dualism is the debatable opposition between emotions and reason, as if only one or the other could shape behaviour at any one time. This disjunction, inherited from the rational actor perspective, ${ }^{11}$ proves to be fragile, because ostensibly any rational calculus also implies a range of affects..$^{12} \mathrm{~A}$ number of scholars have, indeed, argued that emotions support rationality, providing it with salience and goals (Elster 1999), while conversely the cognitive approach defines emotions as 'embodied thoughts, thoughts seeped with the apprehension that 'I am involved' (Rosaldo 1984: 143). As such, they arise out 'of complex cognitive understanding and moral awareness, reflecting our comprehension of the world around us and sometimes of our place in it' (Goodwin et al. 2004: 413).

Emphasizing that feeling pity or anger, for instance, is an active appraisal of a situation, the social constructionist perspective further 'rationalizes' emotions: they are described as 'judgments of situations based on cultural beliefs and values' (Lynch 1990: 8-10), learned or acquired in society. As stressed by Jeff Goodwin, James Jasper and Francesca Polletta:

Moral outrage over feared practices, the shame of spoiled collective identities or the pride of refurbished ones, the indignation of perceived encroachment on traditional rights, the joy of imagining a new and better society and participating in a movement towards that end-none of these are automatic responses. They are related to moral intuitions, felt obligations and rights, and information about 
expected effects, all of which are culturally and historically variables (Goodwin et al. 2001: 13)

51 rationality, since it tends to negate that emotions have subjective or affective aspects in their own right, which, in turn, have an effect on the participants' actions. ${ }^{13}$ Yet, looking at emotions as automatic, patterned responses to particular social stimuli, and even inherently linked to class belonging (Barbalet 2001), poses a range of methodological problems. Just to mention the most obvious one: social scientists work on emotions expressed and interpreted by the actors on the basis of salient (socio-cultural) situational factors, hence the question, "how does one legitimately move from what is observed (the expression) to what cannot be observed (the emotion)?' (Solomon 1984: 246) will remain unanswered.

The second false dualism relates to the causal nature of emotions in mobilizations. In most of the recent literature, there is a palpable uneasiness regarding the 'explanatory power' of emotions in collective actions. Emotions are said to be 'the reason we bother to participate in movements at all, rather than sit on the sideline' (Goodwin et al. 2004: 418) or 'like an unseen lens that colors all our thoughts, actions, perceptions and judgments' (Goodwin et al. 2001: 10). They are described as 'inducing inflexions in experiences and revisions of one's judgment and decisions [...] [as well as] innervating the direction of categories and narratives' (Cefaï 2007: 517, emphasis added). This ambiguity is actually linked to a wider problem: after decades of research and a great number of theoretical works and case studies, we strangely still know very little about the 'passage to action' or how a predisposition to translates into an effective action (or inaction) (Fillieule 2001: 199). What is needed to fill this gap, as stressed by Olivier Fillieule, is an account of the 'activist's trajectory' or 'career'. ${ }^{14}$

The last analytical dualism to be addressed, and an important one for the present volume, concerns the assumed difference between 'expressive' social movements, displaying real emotions, versus 'instrumental' ones manipulating participants' feelings. A new category of research on 'emotional activism' (Walgrave \& Rihoux 2000) sees emotions as an inherent property of a certain type of movements, such as victims' associations. Although it would be tempting to include protests by 'outraged communities' in this type of social movement, the very categorization is scientifically indefensible. If certain movements are 'emotional', then what are the others? Indeed, nothing allows us to assume that anger, shame, hope, affective bonds, etc. do not play as important a role in the trajectories of 'material-reward oriented' movements, such as factory workers taking on to the street to get a raise in their salary. Secondly, the risk here is obviously to substantiate emotions while 'the strategies of self-staging, the constraints of roles, the norms of expressing emotions' (Latté 2006: 1) are all conveniently ignored..$^{15}$

In contrast to the 'emotional activism' approach, the utilitarian perspective puts almost all the emphasis on how social movements' leaders 'manipulate', 'manage' and 'organize' their militants' feelings. In other words, the 'emotions to be mobilized' prevail over the 'mobilizing emotions' (Mathieu 2004: 564). Leaders and activists of social protests certainly strategize what kinds of emotions to stimulate and to display in the public arena. But their calculations also depend on the assumptions they share with the public about how emotions might work; an epistemology of emotion is also at play (Polletta 2001). Moreover, a rigid instrumentalist approach fails to consider that emotions might make sense for the 'entrepreneurs' themselves. For instance, when Reverend Martin

South Asia Multidisciplinary Academic Journal, 2 | 2008 
Luther King employed Christian themes in his speeches and 'brought an [...] accessible frame to the [civil rights] struggle' (McAdam 1996: 347), should we deduce that he made a calculated decision? This would be as far-fetched as saying that he employed English language as a result of a strategic effort. Why not considering that King 'employed Christian themes because, as a Baptist minister with a doctorate in theology, he actually believed that those 'themes' were true or valuable for their own sake' (Goodwin \& Jasper 1999: 49)?

\section{Emotions and 'outraged communities" collective actions: A research agenda} an unavoidable, yet thorny, encounter with psychology that anthropologists, sociologists and political scientists alike are ill equipped to deal with (Braud 1996: 8). An acceptable solution could be to distinguish 'micro-sociological enunciations' from 'psychological enunciations'. As social sciences do not focus, as such, on the individual as an object, 'they do not have to explain the type of motivations, which are linked to his/her peculiar personality' (Braud 1996: 18); in other words, they can bring to surface the sociologically relevant enunciations while putting aside a psychological analysis of an individual's behaviour. This is easier said than done because when we state that actors are 'preoccupied by' or 'sensitive to' any given social, political or economic factor, we cannot avoid a statement on the psychological dimension of their emotion.

methodological solution could be to focus on given situations, and this is precisely what the case studies included in this volume of SAMAJ have attempted to do. This helps to avoid the shortcomings of both the instrumentalist and spontaneous paradigms, each claiming to tell the truth about the individual's state of conscience, either by naturalizing emotions or by searching for 'real' motivations behind the 'emotional mask'. Both fail to take emotions for what they are, that is 'the product of activities whose development is inseparable from a situation's layout' (Jean-Philippe Heurtin quoted in Latté 2006: 1). Indeed:

Emotions are operating in protest at multiple levels, from the micro-level processes by which bystanders become participants, to the emotional repertoires that activists draw upon when pitching their case in different settings, to the organizational mechanisms through which particular emotions are managed, to the macro-structural shifts responsible for making certain emotions legitimate motivations for protest (Goodwin et al. 2004: 414).

As far as individual participation is concerned, emotions obviously do not automatically drive people to join a collective protest. Yet, they certainly act as the 'hot button' that Gamson (1992) talks about. Emotions also inform judgments, how problems are defined and how grievances are shaped. For instance, scholars have puzzled over why state repression in some cases decreases the chance of collective protest while in others it increases it. The answer lays partly, state Goodwin, Jasper and Polletta (2004: 417), in the management of emotions, and particularly of fear. For example: how great is the fear of the police? How strong is the indignation over its repressive policy? Does the sense of moral outrage spread to new parts of the population in response to state repression? Can fear in high-risk activism be mitigated by shaming or by belief in divine protection, hence

South Asia Multidisciplinary Academic Journal, 2 | 2008 
encouraging people to protest despite their apprehension of the dangers involved (Goodwin \& Pfaff 2001)?

This nevertheless leaves aside a crucial component of any collective mobilization: the social movement organization, which is deeply involved in 'emotion work' or 'emotion management' (Hochschild 1979), ${ }^{16}$ trying to change in degree or quality the emotions and feelings motivating and guiding the movement and adapting them to specific conditions and interactions. They have to transform grief into anger, anger into a sense of injustice, and a sense of injustice into hope of change, for instance. Movement organizers work hard to inspire and spread moral emotions, which sometimes define the movement itself: pride (Gay Pride for instance), compassion (animal rights activists) or righteous anger (the 'outraged communities' studied in this volume). They also have to reinforce loyalties and calm fears (Goodwin \& Pfaff 2001). All this 'emotion work' is done while simultaneously complying with the given 'feeling rules', that is the 'guidelines for the assessment of fits and misfits between feeling and situation' (Hochschild 1979: 566).

A. R. Hochschild's concepts prove particularly helpful to overcome the instrumentalist bias. Without succumbing to the 'real' versus 'fake' emotions dichotomy, we are equipped to analyze how "outraged communities" leaders and participants alike perceive, assess, evoke and suppress their own and other people's emotions, while pursuing the movement's goals. We can also pay attention to the particular emotions that are worked upon: do leaders attempt to mobilize primarily compassion, hope, shame or anger in order to attract participants? Do they capitalize on pride and guilt to maintain commitments? Do they work on empathy and sympathy to attract bystanders? And what happens when there are contested beliefs within a movement regarding the appropriate range, intensity and targets of various emotions? In addition, when do movements foster unconventional, 'outlaw emotions' (Jaggar 1989: 161) and when do they encourage, on the contrary, conformity to the dominant rules of the wider society? In analyzing the organizations' work on emotions, we can finally focus on a regular, yet understudied, pattern of collective actions, street demonstrations in particular: the 'emotional warfare' (Goodwin et al. 2004: 417) that protestors engage in with their opponents who are trying to push them to make mistakes out of anger in order to discredit them.

But if the 'emotion work' approach proves particularly useful, emotions are not always programmed, calculated or administered by entrepreneurs and participants alike, they also exist at their pre-reflexive level. Daniel Cefaï (2007: 83) rightly asks: 'Why cannot we accept, and without having to subscribe to an irrationalist vision, that joy, fear, hatred, despair, envy or resentment are collective experiences that have a strong power of mobilization, independently of any project?' While the public and collective expression of emotions in the protest event itself and its rich dramaturgy are precisely where we can study this affectual dimension, strangely, this level of observation is not mentioned in Goodwin, Jasper and Polletta's roadmap recalled above.

61 Collective protests, indeed, have an endogenous character: 'the palpable sense of 'weness' that defines peak moments of collective action is amongst the most emotionally intoxicating and socially connective experience one can have' (Aminzade \& McAdam 2001: 43), as shown by Thomas B. Hansen's contribution in this volume. This certainly does not mean that a single man in a crowd 'does not know himself anymore' (Durkheim 1912: 384). It is simply to recognize that there are strong emotions derived from the activity of protesting: 'collective affection, enthusiasm, joy, even wonder, at possibilities 
for social change; the pride of revaluing a stigmatized identity; the many pleasures of protest from erotic attraction to avoidance of boredom' (Jasper 1997: 108).

Crowds also redefine problematic situations and participate in reshaping moral orders ${ }^{17}$; a point emphasized in works such as those by Elias Canetti (1984) and also developed in Oskar Verkaaik's (2004) work on the Pakistan-based Muhajir Qaumi Movement (MQM). ${ }^{18}$ It is precisely the combination of the ludic character (hence emotional texture) of the MQM's protest events, their transgressive humour, and yet high level of violence, that provided the most powerful means of mobilization. This does not render demonstrators less committed to the cause. Opposing 'excitement-seekers' to 'morally committed' participants is, as a matter of fact, a crucial component of the entrepreneurs' and observers' discourse, especially when riots occur (see Blom in this volume) and the respectability of the movement is to be rescued. Seeking thrill in a political crowd, rather than in a movie hall for instance, actually points to the articulation between emotions and moral visions: 'the feeling of [...] morality' precisely arises in the group members' mutual awareness of their shared focus of attention' and their sense that what one is doing has a higher importance (Collins 2001: 29). Moreover, and importantly, fun is never function-less. In the case, again, of the MQM public manifestations, fun was a matter of uprooting 'ethnic and religious stereotypes through role inversion and grotesque exaggeration' (Verkaaik 2003: 3), thus making the unimagined imaginable and allowing for the escalation of social conflict.

Such an ethnographic analysis of South Asian crowds and publics is, indeed, an extremely fertile path to follow so as to explore the rich and diverse political meaning of outraged mobilizations that is, more often than not, revealed in the easily and popularly accessible language of emotions. Indeed, people gather at places infused with emotional and symbolic meanings, where identities are being narrated while rituals of revenge, reparation, civility or commemoration are being accomplished, and organizations battle with one another through staged threats, attacks and seduction.

Finally, there is a fourth significant level at which the role of emotions in collective action needs to be studied: the 'macro-structural shifts responsible for making certain emotions legitimate motivations for protest' (Goodwin et al. 2004: 414). These shifts have principally been studied in the social movements' emotional culture. Surprisingly, the state, or more broadly what Helen Flam rightly calls the 'emotional-institutional' context within which social movements do their emotion work' (Flam 2005: 19), is barely mentioned. Yet, for specialists of South Asia, wherein the colonial legacy of taming-and simultaneously defining-the 'emotional subject' has been so enduring, the state's 'politics of emotion' is simply impossible to avoid (see Ali, Blom, Hansen in this volume). A case in point is the British Raj's Blasphemy Laws that have been kept almost intact in India, Pakistan and Bangladesh (and strikingly bears the same number, article 295, in both the Indian and Pakistani Penal Codes). The state, through its legal apparatus and instruments of political socialization, but also through the government's manoeuvring (see Riaz in this volume), determines (along with movement organizations) which emotions can legitimately be expressed publicly.

Taking into account the movement's emotion culture while simultaneously looking at the state's might also help to understand why particular 'vocabularies of motives' (Polletta \& Amenta 2001: 309) prevail in certain locations and historical periods, while others disappear or decline. Why was hatred directed against India a legitimate emotion to display in Pakistan's streets for decades but declined after 2001, while hatred for Pakistan 
has become, again, a permissible public emotion in India in the post-2008 Mumbai attack context ${ }^{19}$ This inquiry is particularly important for us at a wider level: why was 'protecting community symbols' a prominent discourse in the 1910s and 1920s, and then again, although it never fully disappeared in the meantime, since the 1980s?

\section{The contributors}

66 Thomas Blom Hansen's contribution elaborates on the nexus between fire, violence and collective sentiments in India. Drawing on material from Mumbai and elsewhere, it reflects upon the fact that most collective violence never has any clear actors, or even people claiming public responsibility or providing justification for their actions. He argues that in a country saturated in political rhetoric, acts of violence tend to acquire their own semiotic register; a singular form of 'political communication'. They are represented as 'pure events', spontaneous combustion or spontaneous rage that arises from perceived collective grievances and insults. Fire is critically important in this process of naturalizing violence: it is not only one of the densest cultural signifiers in India, but also at the heart of the transgressions, the exceptions, the taboos, the sacrifices, the agency, the sense of communitas that unfolds in times of heightened conflict with the state or with other communities.

In his ethnographic study of how anger becomes expressed publicly by the powerless, Nicolas Jaoul brings to our attention a Dalit ('untouchable') protest movement against caste violence (the 2006 Khairlanji massacre). Although anger is supposedly an emotion used in an open and performative manner by the powerful to enact their domination, the Dalit movement has engaged in an 'emotion work' that upsets such a social mapping of emotions. The protest's ideological content and framing of outrage illustrates the process of social appropriation of anger by weaker sections of society as well as the politically marginalized Dalits' appropriation of democratic conceptions through the vernacular language of injustice and outrage to their human dignity. The paper also critically discusses the sterile and biased concept of 'axiological neutrality' and advocates instead a reflection on the heuristic possibilities entailed in the ethnographers' personal exposure to such an emotion work done by social movements.

Amélie Blom explores how long-distance outrages can provoke social protests, and even riots. The demonstration against the Danish cartoons that took place in Lahore on $14^{\text {th }}$ February 2006 was primarily an expressive protest, publicly voicing its anger and moral discontent. As such, it offers a fruitful micro-political site to understand how emotions contribute to shape the culture of dissent in contemporary Pakistan. Based on interviews with protestors, this article elaborates, first, on the linkages between anger, honour, the cognitively framed belief of being 'provoked' and biographically embedded emotional repertoires. Second, it looks at the conflicting emotions displayed in the public arena during the protest itself: a desire of communitas, yet of destruction, an expression of compulsory feelings, yet of subversive emotions. Finally, it argues that this protest takes its full meaning only once replaced in the larger framework of the state's singular politics of emotion that informs public debates in Pakistan, and particularly so in Punjab.

Nosheen Ali examines the 'textbook controversy' (2000-2005) that arose when the Pakistani state introduced new, overtly Sunni textbooks in the Northern Areas, and the local Shia population began to agitate for a more balanced curriculum. The conflict reached an acute stage during 2004-2005, as violent confrontations took place between 
Shia and Sunni communities, and a constant curfew paralyzed daily life in Gilgit for eleven months. She stresses that the Shia mobilization against the textbook was not just another form of 'sectarian' outrage; rather it symbolized a broader political claim to inclusion in a context of long-standing regional subordination and religious suppression. The politics of sectarian emotions in the Northern Areas must therefore be understood in relation to the regulatory processes of state-making, which are the very source and embodiment of 'sectarianism' and 'outrage' in the region.

In his contribution Ali Riaz also stresses the importance of 'bringing the state back in' so as to explain the reactions to Taslima Nasreen's perceived outrage. The exiled Bangladeshi writer was forced to leave India in 2008 following street agitation against her writings in Kolkata. The events, which unfolded from the moment she was physically attacked in Hyderabad to the time she was forced to leave the country, were reminiscent of what happened in Bangladesh in 1994. In both instances, 'outraged communities' were constructed, and symbols invented to mobilize the community. More importantly, in both cases, the state forcibly removed Nasreen from the country to placate the agitators. This article not only gives a detailed account of the events on the ground but also highlights the importance of state responses to perceived outrage; an aspect which has received little attention in the extant discussions over this controversy.

71 Pierre Centlivres analyzes a challenging case of ambiguous and mirror-outrage: the destruction of the Buddhas of Bamiyan (Afghanistan) that opposed the Taliban and the international community in 2001. He stresses the multi-faceted meanings of outrage and the uncertainty characterizing the identification of the victims of the outrage: were they the people in general, abstract deities, specific communities? The article then elaborates on the argumentation and self-justifications presented by the Taliban, their sense of indignation at a protest coming from 'Christian' countries, exclusively concerned with saving 'idols' but ignorant of the ordeal endured by the Afghans. It finally shows that conflicting visions over the very meaning of 'cultural heritage' were at the core of the worldwide controversy.

Charlène Simon and Lionel Baixas focus on a protest, which started in Indian Punjab in May 2007. It followed a ceremony performed by Baba Gurmeet Ram Raheem Singh, the head of Dera Sacha Sauda, a peripheral Sikh sect whose membership mostly comprises of Dalits. This ceremony was considered blasphemous by a section of the Sikh community, since the religious leader had taken the appearance of the tenth Sikh Guru. This study explores the reasons that have led hundreds of Sikhs from very different social backgrounds to take to the streets. One year later the authors look at how protestors justify their participation in the protest and analyze the different definitions of what it means to be a Sikh that came up during the mobilization. The authors emphasize the pride to mobilize spontaneously and react immediately against an insult to the faith. They argue that this very event contributed to enforce the perception of the Sikhs as the archetype of the outraged community.

Christophe Jaffrelot examines the difficulties of Hindu nationalists' endeavour to mobilize against the construction of the Ram Setu bridge between Sri Lanka and India in 2007. Sangh Parivar activists have become experts in the art of being outraged. They articulate a deep-rooted Hindu majoritarian inferiority complex, and usually denounce the disrespectful behaviour of the minorities, especially the Muslims, in order to mobilize followers and polarize the society along communal lines. The controversy about the Ram Setu also follows this pattern. But this time mobilizing and constructing the outrage 
proved much more complicated as the enemies deemed responsible for the victimization of the Hindus were not Muslims or Christians, but the state and born Hindus. In this interesting case of failed outrage, the Hindutva leaders appeared to be less concerned by the sacred character of the symbol, hence revealing their present quest for non-religious reasons, such as economic and strategic ones, for defending an object of outrage.

\section{Conclusion}

This second issue of SAMAJ does not aim at replacing one causal model of collective mobilization by another that would make emotions explain everything 'else' that could not be explained before. But it does hope to contribute to a better, and empirically grounded, understanding of the emotional dynamics of collective mobilizations provoked by perceived outrages in South Asia. In doing so, we hope to respond, partially of course, to the invitation made by Ronald Aminzade and Doug McAdam (2002: 109) that 'further research is needed before we can make any strong generalizations concerning the relationship between appeals to particular emotions and particular types of movements, movement cultures, or collective action repertoires'. The eight case studies included in this volume are certainly far from providing a complete picture and represent only a tentative attempt to stress the importance of moral outrage in South Asian collective action. Yet, the narratives and staging of outrage analyzed here provide a rich material that may shed some light on the underlying rationale, shared values and deep contradictions of the politics of dissent in South Asia, whether in street politics or through less conventional, and less noticed, forms of protest.

\section{BIBLIOGRAPHIE}

Assayag, Jackie (2001) L'Inde: désir de nation, Paris: Odile Jacob.

Aminzade, Ronald R.; McAdam, Doug (2001) 'Emotions and Contentious Politics', in Ronald Aminzade, Jack A. Goldstone, Doug McAdam, Elizabeth J. Perry, William H. Sewell, Sidney Tarrow \& Charles Tilly (eds.), Silence and Voice in the Study of Contentious Politics, Cambridge: Cambridge University Press, pp. 14-50.

Ronald Aminzade; Doug McAdam (2002) 'Emotions and Contentious Politics', Mobilization, Special Issue on 'Emotions and Contentious Politics', 7(2), 2002, pp. 107-9.

Baily, C. A. (1985) 'The Prehistory of 'Communalism'? Religious Conflict in India, 1700-1860', Modern Asian Studies, 19(2), pp. 177-203.

Barbalet, Jack (2001) Emotions, Social Theory, and Social Structure: A Macrosociological Approach, Cambridge: Cambridge University Press.

Basu, Tapan (ed.) (1993) Khaki Shorts and Saffron Flags: A Critique of the Hindu Right, Tracts for the Times/1, New Delhi: Orient Longman. 
Benford, Robert (1997) 'An Insider's Critique of the Social Movement Framing Perspective', Sociological Inquiry, 67, pp. 409-30.

Boltanski, Luc; Thévenot, Laurent (1991) De la Justification: les économies de la grandeur, Paris: Gallimard.

Bouchet, Thomas (2005) 'A la recherche de l'insulte (en) politique', in Thomas Bouchet (ed.), L'Insulte (en) politique: Europe et Amérique latine du XIXe siècle à nos jours, Dijon: Editions Universitaires de Dijon, pp. 7-12.

Brass, Paul R. (1998) The Theft of an Idol, Calcutta: Seagull.

Braud, Philippe (1996) L'émotion en politique, Paris: Presses de Sciences Po.

Canetti, Elias (1984) Crowds and Power, New York: Farrar, Straus and Giroux [1960].

Cheyronnaud, Jacques; Lenclus, Gérard (1992) 'Le blasphème d'un mot', Ethnologie française, Numéro spécial 'Paroles d'outrage’, 22 (3), pp. 261-70.

Cefaï, Daniel (2007) Pourquoi se mobilise-t-on? Les théories de l'action collective, Paris: La DécouverteMAUSS.

Collins, Randall (2001) 'Social Movements and the Focus of Emotional Attention', in Jeff Goodwin, James Jasper \& Francesca Polletta (eds.), Passionate Politics: Emotions and Social Movements, Chicago: University of Chicago Press, pp. 27-44.

Das, Veena (1998) 'Specificities: Official Narratives, Rumour, and the Social Production of Hate', Social Identities, 4 (1), pp. 109-30.

Durkheim, Emile (1991) Les formes élémentaires de la vie religieuse, Paris: Livre de poche, [1912].

Elster, Jon (1999) Alchemies of the Mind: Rationality and the Emotions, Cambridge: Cambridge University Press.

Favret-Saada, Jeanne (1992) 'Rushdie et compagnie. Préalables à une anthropologie du blasphème', Ethnologie française, Numéro spécial ‘Paroles d'outrage', 22 (3), pp. 251-60.

Fillieule, Olivier (2001) 'Propositions pour une analyse processuelle de l'engagement individuel', Revue française de science politique, 51 (2), pp. 199-217.

Flam, Helena (2005) 'Emotions' Map: A Research Agenda', in Helena Flam \& Debra King (eds.), Emotions and Social Movements, New York: Routledge, pp. 19-40.

Freitag, Sandria B. (1989) Collective Action and Community: Public Arenas and the Emergence of Communalism in North India, Berkeley: University of California Press.

Freitag, Sandria B. (1996) 'Contesting in Public: Colonial Legacies and Contemporary Communalism', in David Ludden (ed.), Making India Hindu, New Delhi: Oxford University Press.

Gaborieau, Marc (1985) 'From Al-Beruni to Jinnah: Idiom, Ritual and the Ideology of the HinduMuslim Confrontation in South Asia', Anthropology Today, 1(3), pp. 7-14.

Gamson, William (1992) Talking Politics, Cambridge: Cambridge University Press.

Goodin, Robert E.; Klingemann, Hans-Dieter (1996) ‘Political Science: The Discipline’, in Robert E. Goodin \& Hans-Dieter Klingemann (eds.), A New Handbook of Political Science, Oxford: Oxford University Press, 1996, pp. 3-49.

Goodwin, Jeff; Pfaff, Steven (2001), 'Emotion Work in High-Risk Social Movements: Managing Fears in the US and East German Civil Rights Movement', in Jeff Goodwin, James Jasper \& 
Francesca Polletta (eds.), Passionate Politics: Emotions and Social Movements, Chicago: University of Chicago Press, pp. 282-302.

Goodwin, Jeff; Jasper, James (1999) 'Caught in a Winding, Snarling Vine: The Structural Bias of Political Process Theory', Sociological Forum, 14(1), pp. 27-55.

Goodwin, Jeff; Jasper, James; Polletta, Francesca (2004) 'Emotional Dimensions of Social Movements', in David A. Snow, Sarah A. Soule \& Hanspeter Kriesi (eds.), The Blackwell Companion to Social Movements, Malden (USA): Blackwell, pp. 413-32.

Goodwin, Jeff; Jasper, James; Polletta, Francesca (2001) 'Introduction: Why Emotions Matter', in Jeff Goodwin, James Jasper \& Francesca Polletta (eds.), Passionate Politics: Emotions and Social Movements, Chicago: University of Chicago Press, pp. 1-24.

Gooptu, Nandini (2001) The Politics of the Urban Poor in Early Twentieth-Century India, Cambridge: Cambridge University Press.

Groves, Julian McAllister (1995) 'Learning to Feel: The Neglected Sociology of Social Movements', The Editorial Board of the Sociological Review, 1995, pp. 435-61.

Hansen, Thomas B. (2005) 'Sovereigns Beyond the State: On Legality and Public Authority in India', in Ravinder Kaur (ed.), Religion, Violence and Political Mobilisation in South Asia, New Delhi: Sage publications, pp. 109-44.

Haroche, Claudine; Vatin, Jean-Claude (1998) 'Avant-propos', in Claudine Haroche \& Jean-Claude Vatin (eds.), La considération, Paris: Desclée de Brouwer.

Heuzé, Djallal (forthcoming) 'Between Shakha and Mandal: The Shiv Sena and the Neighbourhood Clubs in Mumbai', in Daniela Berti, Nicolas Jaoul \& Pralay Kanungo (eds.), The Cultural Entrenchment of Hindutva: Local Mediations and Forms of Resistance.

Holmes, Mary (2004), 'The Importance of Being Angry: Anger in Political Life', European Journal of Social Theory, Special Issue on 'Anger in Political Life', 7(2), pp. 123-32.

Hochschild, Arlie Russell (1979) 'Emotions Work, Feeling Rules, and Social Structure', American Journal of Sociology, 85, pp. 551-75.

Jaffrelot, Christophe (1996) The Hindu Nationalist Movement and Indian politics, New York: Columbia University Press.

Jaggar, Alison (1989) 'Love and Knowledge: Emotion in Feminist Epistemology', in Alison Jaggar \& Susan R. Bordo (eds.), Gender/Body/Knowledge: Feminist Reconstruction of Being and Knowing, New Brunswick: Rutgers University Press, pp. 145-71.

Jasper, James (1997) The Art of Moral Protest: Culture, Biography and Creativity in Social Movements, Chicago: University of Chicago Press.

Larguèche, Evelyne (2004) 'L'injure comme objet anthropologique', REMMM, Numéro spécial 'L'Injure, la société, l'islam : une anthropologie de l'injure', 103-4, pp. 29-56.

Latté, Stéphane (2006) “Vous ne respectez pas les morts d'AZF'. Ordonner l'émotion dans les situations commémoratives', Colloque: Mobilisation de victimes, Centre de Recherches Politiques de la Sorbonne (CRPS), 15-16 June, Unpublished paper.

Le Monde. 2008. 'Les paysans indiens poussent Tata à retarder la fabrication de la Nano', 6 September.

Lutz, Katherine; White, Geoffrey (1986) 'The Anthropology of Emotions', Annual Review of Anthropology, 15, pp. 405-36. 
Lyman, Peter (1981) ‘The Politics of Anger', Socialist Review, 11, pp. 55-74.

Lynch, Owen (1990) 'The Social Construction of Emotions in India', in Owen Lynch (ed.), Divine Passions: The Social Construction of Emotion in India, Berkeley: University of California Press, pp. 3-34.

McAdam, Doug (1982) Political Process and the Development of Black Insurgency, 1930-1970, Chicago: Chicago University Press.

Mariot, Nicolas (2001) 'Les formes élémentaires de l'effervescence collective ou l'état d'esprit prêté aux foules', Revue française de science politique, 51(5), October, pp. 707-38.

Mathieu, Lilian (2004) 'Des mouvements contestataires à la politique contestataire: les voies tâtonnantes d'un renouvellement de perspective', Revue Française de Sociologie, 45 (3), pp. 561-80.

Ost, David (2004) 'Politics as the Mobilizing of Anger', European Journal of Social Theory, 7(2), pp. 229-44.

Pandey, Gyan (1990) The Construction of Communalism in North India, Delhi: Oxford University Press. Polletta, Francesca (2001) ‘The Law of Passion', Law and Society Review, 35, pp. 467-93.

Polletta, Francesca; Amenta, Edwin (2001) ‘Conclusion: Second that Emotion?', in Jeff Goodwin, James Jasper \& Francesca Polletta (eds.), Passionate Politics: Emotions and Social Movements, Chicago: University of Chicago Press, pp. 304-16.

Poutignat, Philippe; Streiff-Frenart, Jocelyne (1995) Théories de l'Ethnicité, Paris : P.U.F.

Rosaldo, Michelle Z. (1984) 'Towards an Anthropology of Self and Feeling', in Richard Shweder \& Robert LeVine (eds.), Culture Theory: Essays on Mind, Self, and Emotions, Cambridge: Cambridge University Press, pp. 137-57.

Rouayrenc, Catherine (1996) Les gros mots, Paris: PUF.

Solomon, Robert C. (1984) 'Getting Angry: The Jamesian Theory of Emotion in Anthropology', in Richard A. Shweder \& Robert A. LeVine (eds.), Culture Theory: Essays on Mind, Self and Emotions, Cambridge: Cambridge University Press, pp. 238-54.

Snow, David; Bedford, Robert (1992) 'Master Frames and Cycle of Protest', in Aldon Morris \& Carol McClurg Mueller (eds.), Frontiers in Social Movement Theory, New Haven: Yale University Press, pp. 133-55.

Scott, James C. (1990) Hidden Transcripts: Domination and the Arts of Resistance, New Haven: Yale University Press.

Scott, James C. (1985) Weapons of the Weak: Everyday Form of Peasant Resistance, New Haven: Yale University Press.

Scott, James C. (1976) The Moral Economy of the Peasant, New Haven: Yale University Press.

Tambiah, Stanley (1996) Leveling Crowds: Ethnonationalist Conflicts and Collective Violence in South Asia, Berkeley: University of California Press.

Thévenot, Laurent (1995) ‘Emotions et évaluations dans les coordinations publiques', in Patricia Paperman \& Ruwen Ogien (eds.), La couleur des pensées: émotions, sentiments, intentions (Raisons pratiques n6), Paris: Ed. de l'EHESS, pp. 145-74.

Thoits, Peggy (1989) ‘The Sociology of Emotions’, Annual Review of Sociology, 15, pp. 317-42. 
Thompson, E. P. (1991) ‘The Moral Economy of the English Crowd in the Eighteenth century', in E. P. Thompson, Customs in Common: Studies in Traditional Popular Culture, New York: The New Press, pp. 185-258, [1971].

Thompson, E. P. (1991) 'The Moral Economy Reviewed', in E. P. Thompson, Customs in Common: Studies in Traditional Popular Culture, New York: The New Press, pp. 259-351, [1971].

Tilly, Charles (1986) The Contentious French: Four Centuries of Popular Struggle, Cambridge: Harvard University Press.

Verdo, Geneviève (2005) 'Places: Introduction', in Thomas Bouchet (ed.), L'Insulte (en) politique: Europe et Amérique latine du XIXe siècle à nos jours, Dijon: Editions Universitaires de Dijon, pp. 15-16.

Verkaaik, Oskar (2004) Migrants and Militants: Fun and Urban Violence in Pakistan, Princeton: Princeton University Press.

Verkaaik, Oskar (2003) 'Fun and Violence: Ethnocide and the Effervescence of Collective Aggression', Social Anthropology, 11(1), pp. 3-22.

Walgrave, Stefaan; Rihoux, Benoît (2000) ‘Une nouvelle militance 'émotionnelle’? Une analyse empirique des militants du mouvement blanc', in José Gotovitch \& Anne Morelli (eds.), Militantisme et militants, Bruxelles: Ed. Couleur Savoir EVO, pp. 194-215.

\section{NOTES}

1. As Djallal Heuzé (forthcoming) suggests in a paper on the Shiv Sena affiliated clubs in Mumbai. The marketing potential of this symbol all over the Subcontinent is also used by, for instance, Pakistani leader Nawaz Sharif, who labels himself as 'the tiger of Punjab'.

2. The contributions to this special issue emerged initially from the first SAMAJ International Conference on "Outraged Communities': Investigating the Politicization of Emotions in South Asia', organized by the co-editors at the Musée du Quai Branly in Paris on September 25-26, 2008. We express our gratitude to the Musée du Quai Branly's anthropological research department (and a special one to the research department staff for their extensive support), to the Centre d'Etudes de l'Inde et de l'Asie du Sud (CEIAS-EHESS) and to the Centre d'Etudes et de Recherches Internationales (CERI-Sciences-Po.), all of whom were co-sponsors of this event. We would also like to thank the participants and discussants at the conference, and more particularly Jacques Pouchepadass who also made valuable comments on this introduction. Additionally, this article has greatly benefited from Mariam Mufti's English editing.

3. The four others are: processions (1); rallies, vigorous appeals to primordial feelings, demonization of the enemy (2); 'standardized forms of intimidation of the opponent', violent acts (3); bribes that facilitate the movements of crowds (4).

4. The 'moral economy', an economy of subsistence, is based on the traditional links of patronage, as opposed to the emerging capitalist economy.

5. A 'moral shock' can be enhancing but may also lead to passivity whenever the offended see themselves as victims of forces beyond their control. People's biographies (whose importance Jasper emphasizes as well), their personal liking or disliking of being in a crowd, the organization's strategies and resource mobilization, the state's repressive or facilitating policies etc., are all factors that, in addition, motivate, rationalize and channel political action.

6. This analogy is all the more helpful because, in some cases, the mechanism simply fails to clutch, as shown by Christophe Jaffrelot's contribution to this volume on the 'Hindu nationalists' (not so easy) art of being outraged'. 
7. We are very grateful to Jérémie Codron for this perceptive comment about the 'Nasreen controversy'.

8. Aristotle wrote in The Rhetoric: 'Take for instance the emotion of anger: here we must discover what the state of mind of the angry people is, who the people are with whom they usually get angry, and on what grounds they get angry with them. It is not enough to know the answers to one or even two of these questions. Unless we know all three, we shall be unable to arouse anger in anyone' (quoted in Lynch 1990: 8). This is, as stressed by Owen Lynch, a particularly modern intuition as emotion is not merely placed in the mind but also in a socio-cultural context.

9. Emotions are defined at this stage as 'any affective state which moves away from this zero degree that complete indifference towards an object is' (Braud 1996: 8).

10. A frame is 'an interpretive schemata that simplifies and condenses the 'world out there' by selectively punctuating and encoding objects, situations, events, experiences, and sequences of actions within one's present or past environment' (Snow \& Bedford 1992: 136-37).

11. A perspective, which paradoxically reproduced 'the putative contrast between emotion and rationality' (Goodwin et al. 2004: 415) prevailing in the 'collective behaviour' approach before.

12. Affects such as 'the passion to control situations of uncertainty, the quest for maximal efficiency' and 'a need to assert oneself, without forgetting the pleasure of playing strategic games' (Braud 1996: 43).

13. We are grateful to Nandini Gooptu for this insightful comment.

14. A 'career' is here understood objectively as status and jobs, but also, and more interestingly, subjectively: as changes in the ways the individual perceives his existence and interprets the meaning of his actions and what happens to him.

15. This is problematic because even the most detailed study of highly 'emotional activism' such as the animal rights movement demonstrates that emotions 'emerge and develop during the process of becoming an activist, when challenged by outsiders or the activists themselves' (Groves 1995: 457).

16. Arlie Russell Hochschild uses these two notions synonymously.

17. See in this regard, French sociologist Daniel Cefaï's pledge for reopening the box of the collective behaviour, particularly the legacy of Robert Ezra Parks, one of the founders of the 'collective behaviour' school at Chicago University (Cefaï 2007: 43-53).

18. The MQM is a political organization that was established in 1984 claiming to represent the Urdu-speaking migrants who left India for Pakistan in and after 1947.

19. Similarly we can ask why, for instance, did 'rage' become a prominent discourse among the French suburban youth in the 1980s.

\section{AUTEURS}

\section{AMÉLIE BLOM}

Visiting Faculty in Political Sociology, Lahore University of Management Sciences (School of

Humanities, Social Sciences and Law)

NICOLAS JAOUL

Researcher in Anthropology, CNRS/IRIS (Paris) 